ホルモンとサーカデアン・リズム

守和子

産業医学総合研究所

はじめに

われわれの睡眠・覚醒のリズムのように, 約 24時間の周期を持つ生体リズム（biorhythm） をサーカデアン・リズム (circadian rhythm) という。circadian という語は1959年 Halberg がラテン語の circa（打打よそ）とdies（1日） とを合成して作ったもので，現在，一般に広く 用いられている。日本では同じ現象のてとを日 内リズム, 日周リズム, 概日リズムなどとも呼 ぶ。恒常環境条件下でのサーカデアン・リズム を自由継続リズム（free-running rhythm） と呼ぶが，乙の場合の周期がちょうど24時間で あるととはほとんどなく，いくらかずれた周期 を示す。AsCHOFF（1967）は地下の防音実験 室を用いて，25時間前後の睡眠周期を得た。し かし，例えば，24時間の明暗サイクルのもとで は, それに同調してちょうど 24 時間の周期をも つようになる。

自然の環境サイクルのあとで生活していた人 間む, 文明の発達とと屯に，人工的な環境サイ クルを加味した環境下で生活するようになり, とくに，急激な環境サイクルの変化を余儀なく される場合が起とって来た。ジェット機で10時 間む飛べば, 地球の裏側へいってしまい, そこ で，時差を経験する。勤務形態のなかに，夜 勤, 昼夜交代勤務, または, 不規則勤務が取入 れられ, 夜働いて, 昼寝る生活をする人が出て 来た。乙のような, 新しい環境サイクルへの同 調はどのようになるのかは現実の問題として重 要である。こてでは, このような問題をホルモ ンを例にとって，われわれの研究とスウェーデ ンの Levi一門の研究を中心に述べる。
1. ホルモンのサーカデアン・リズム研究の概 要

ホルモンのサーカデアン・リズムの研究は 1943年 PINCUS がヒトの尿中 17-ケトステロ イド（17-KS）の排泄にサーカデアン・リズム があるととを報告したのにはじまる。なお, 17-KS は副腎皮質ホルモンである cortisol の 代謝物の中の一グループである。そして, 視床 下部一脳下垂体一副腎皮質系のサーカデアン・ リズムが集中的に研究された。視床下部で作ら れる $\mathrm{ACTH}$ 放出因子 (CRF) が脳下垂体を 刺激して副腎皮質刺激ホルモン（ACTH）を 放出させ，それがさらに副腎皮質ホルモンの生 産を促すという関係はよく知られている。視床 下部に拈ける CRF の活性 (HiROSHIGE et al., 1969), 血中 ACTH レベル (NEY et al., 1963），血中あるいは尿中の副腎皮質ホルモン ・レベルのいずれにもサーカデアン・リズムが 存在し,それらの変動の間には高い相関が認め られる。図1にラットの血中コルチコステロン

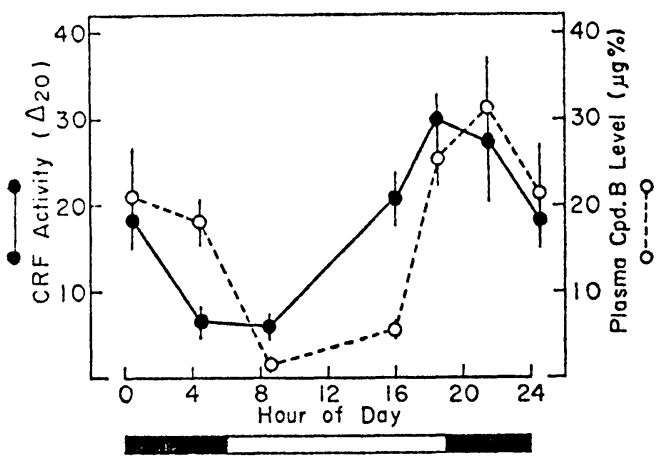

Fig. 1. Circadian rhythms of CRF activity in the hypothalamus and plasma corticosterone of normal male rats (HIROSHIGE et al., 1969). 
(Compound B) と視床下部正中隆起 部の $\mathrm{CRF}$ 活性のサーカデアン・リズムの関係を示 した（HIROSHIGE et al., 1969)。ラットの活 動期は夜間であるから，夜間の值が昼間にくら べて高值であるが，活動期が㡺間である正常人 ではリズムは逆となり，血漿 ACTH および cortisol は午前 4 時ごろより上昇しはじめ，午 前 $6 \sim 8$ 時に最高值に達し, 以後漸減して午後 10 時〜午前 1 時でろに最低值になる。今まで述 べてきたととによるとホルモンのサーカデアン ・リズムはなめらかな曲線を描いているように 考えられる。しかし, HeLLMAN et al. (1970) がヒトの cortisol の分泌動態を細かく調べた ところ，1 日中連続的に分泌されておらず， episodic（律動的）に分泌されていることがわ かった。 1 日の分泌時間は合計約 6 時間，あと の18時間は全く分泌してないという。GALLAGHER et al. (1973) は午前 1 時より 9 時まで 5 分間隔で血中 ACTH と cortisol を測定 し, ACTH の episodic secretionはかなり 頻回に起こるととを指摘している。cortisol, ACTH に episodic secretion があるので, さらに上位の CRF 分泌パターンにも episodic な変動があるのであろうが，実験方法などに問 題があり，現在の所わかっていない。CRF の サーカデアン・リズムに影響する中枢神経系か らの入力様式に関連して, 脳内活性アミンの役 割などが注目されている（広重，1972）。

ACTH 以外の下垂体前葉ホルモンの中, 一 見サーカデアン・リズムを示すものに成長ホル モン $(\mathrm{GH})$ とプロラクチンがあるが，乙れら は睡眠パターンを変えるとすぐそのパターンに 同調するので，睡眠一覚醒サイクルにただちに 影響されない ACTH とは異なる。しかし， 上記 3 ホルモンと黄体形成ホルモン (LH), 卵 胞刺激ホルモン (FSH), 甲状腺刺激ホルモン (TSH) の 6 種の前葉ホルモンに共通してい るのは episodic secretion を示すととである (広重, 1972；井村, 1976)。
水代謝 にはサーカデアン・リズムがあるこ とは古くから知られているが，尿量のリズムが 血中抗利尿ホルモン $(\mathrm{ADH})$ の変動とよく一 致することから尿量のリズムは血中 $\mathrm{ADH}$ の リズムによると推論するものもいるが，異論を はさむむのあいる。なお，尿量は夜少なく，昼 多く, 血中 $\mathrm{ADH}$ 值は夜高く, 昼低いサ一カ デアン・リズムを示す（吉田，1972）。

松果体のホルモンであるメラトニンとセロト ニンに白顕著なサーカデアン・リズムが存在 し，両者のリズムは逆の関係にあり，乙れはセ ロトニンーN-アセチル転移酵素活性のリズムに よってひきおてされるといわれている（出口， 1975)。メラトニンとセロトニンはインドール アミンに属する生体アミンで，カテコールアミ ンに属するノルアドレナリンとドーパミンとと むに脳内活性アミンとして, 今後, サ一カデア ン・リズムの発現機構を解く上に重要なものに なるであらう。

2. 睡眠一覚醒サイクルとサーカデアン・リズ 厶

ホルモンの中にはサーカデアン・リズムを示 すすのが数多くみつかり, サーカデアン・リズ ム以外の周期性変動も, そのほとんどがサーカ デアン・リズムに還元できるのではないかとの 説もある（出口，1975）。しかし，急激な環境 サイクルの変化に対するヒトの適応の問題とな るとサンプリングの問題などがからんでくるた めか測定項目にかぎりがあるのが現状のようで ある。また，乙れらホルモンの測定が radioimmnoassay によるむのが多く，その歴史の新し いととにもよると思われる。睡眠一覚醒サイク ルの変化にとむなうサーカデアン・リズムの変 動の指標として一番よく使用されているのは体 温であろう。体温の測定はジェット機の中で む, 家庭でも容易に出来るし, 体温には外的要 因によって変わりにくいサーカデアン・リズム が存在するので測定項目としては好都合なもの である。次に尿中成分があげられよう。採尿は 
採血に比較して, 長期間の頻回の採取が容易で あり, かつ, その成分の中には, 副腎皮質ホル モン, 水, 電解質などサーカデアン・リズムを 示すすのをふくんでいる。従って，われわれあ 交代制勤務者のサーカデアン・リズムを検討す る目的で，体温などの測定とともに尿中成分の 変動を調べた。

1）日常生活時のサーカデアン・リズム

まず，実験室内で日常生活をさせた場合のサ 一カデアン・リズムについて検討した（守ら， 1971; 守, 1973a)。副腎皮質ホルモン cortisol の代謝物として，尿中に排泄されるものは側鎖 の残っているむのとして, tetrahydrocortisol (THF), allo-tetra-hydrocortisol ( $a$-THF), tetrahydrocortisone (THE), cortolone, $\beta$ cortolone, cortol, $\beta$-cortol などがある。その 他に側鎖が切れた種々の 17-ケトステロイドが ある。昇温ガスクロマトグラフを用い, 前者が よく分離する条件を選んだ。しかし，THF と $a$-THF のピークは分離しなかったので，和で 表わすてととした。日常生活をしている10名の 被験者について，3 時間毎に採尿し，各人の 24 時間の平均值に対する百分率として各分画值を 算出し, その值の 10 名の平均值を求めた。 $\mathrm{THF}$ $+a$-THF と THE は振幅の大きい早朝立ち上 がる固有のサーカデアン・リズムを持つが, cortolone, $\beta$-cortolone では早朝の立ち上がり が鈍く, $\beta$-cortolone では振幅がやや小さかっ た（守, 1973a)。

2）昼夜逆転生活時とその回復過程における サーカデアン・リズムのみだれ。

2 日間の昼夜逆転生活とそれに続く 2 日間の 昼夜正常生活の間のサーカデアン・リズムのみ だれとその回復について検討した（守, 1974a； 守, 1975a)。被験者は男子学生 4 名で, スケジ ュールの大要は図 2 の上段に示した。実験は 18 時にスタートし, 最初の丸 2 日間は昼夜逆転生 活, 続く丸 2 日間は昼夜正常生活をさせ, 2 日 目と 3 日目の間は息抜きの自由時間とし, 入
浴，散歩などをさせた。それを除く，覚醒中の 大部分は図に示したように麻雀ゲームを負荷し た。その間, 約 3 時間毎に採尿し, 舌下温, 脈 拍数, 血圧, 単純反応時間を測定し, 自覚症状 しらべなどを行なった。図 2 に舌下温, 脈拍数 の変動を, 図 3 亿尿中の cortisol の代謝物の 変動を, 図 4 亿尿中の遊離型カテコールアミン
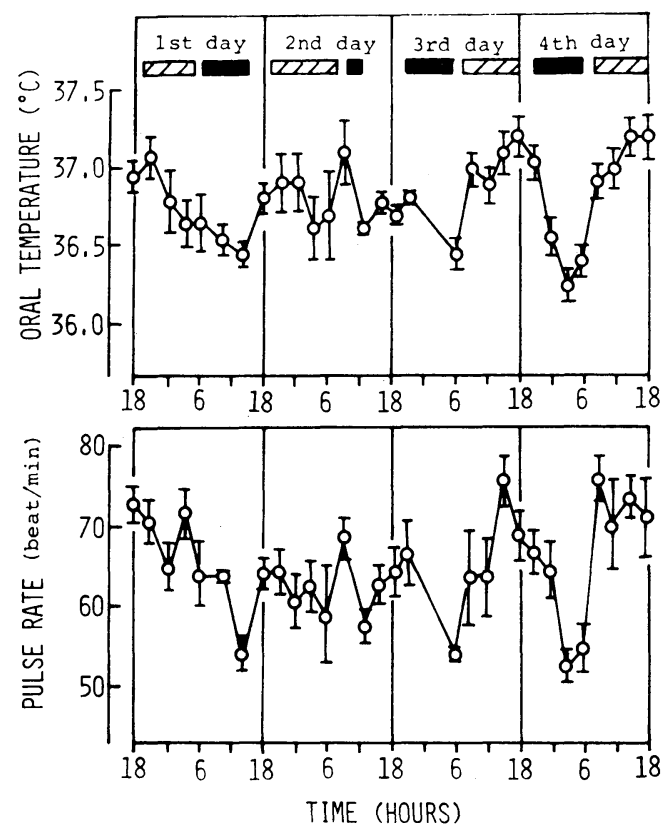

Fig. 2. Means and standard errors of the means of oral temperature and pulse rate in reversed (2 days) and normal (2 days) lives of sleep-waking cycle.

- Sleep, YU//// Game (MORI, 1974a).

の変動を示した。舌下温は第 1 日目から完全な リズムの逆転は示さないが，かなりの平坦化が みられる。乙れは van LOON (1963) の昼夜 逆転生活 4 日目, 5 日目のパターンと類似する あのである。第 2 日目は第 1 日目と生活パター ンがやや異なり，その影響むみられるが，全体 的にはやはり平坦化している。第 3 日目の起床 時から後は日常生活と同様のパターンを示す。 つまり, 昼夜逆転生活時, 生活パターンにかな りそって変化はするが，逆転までには至らな 

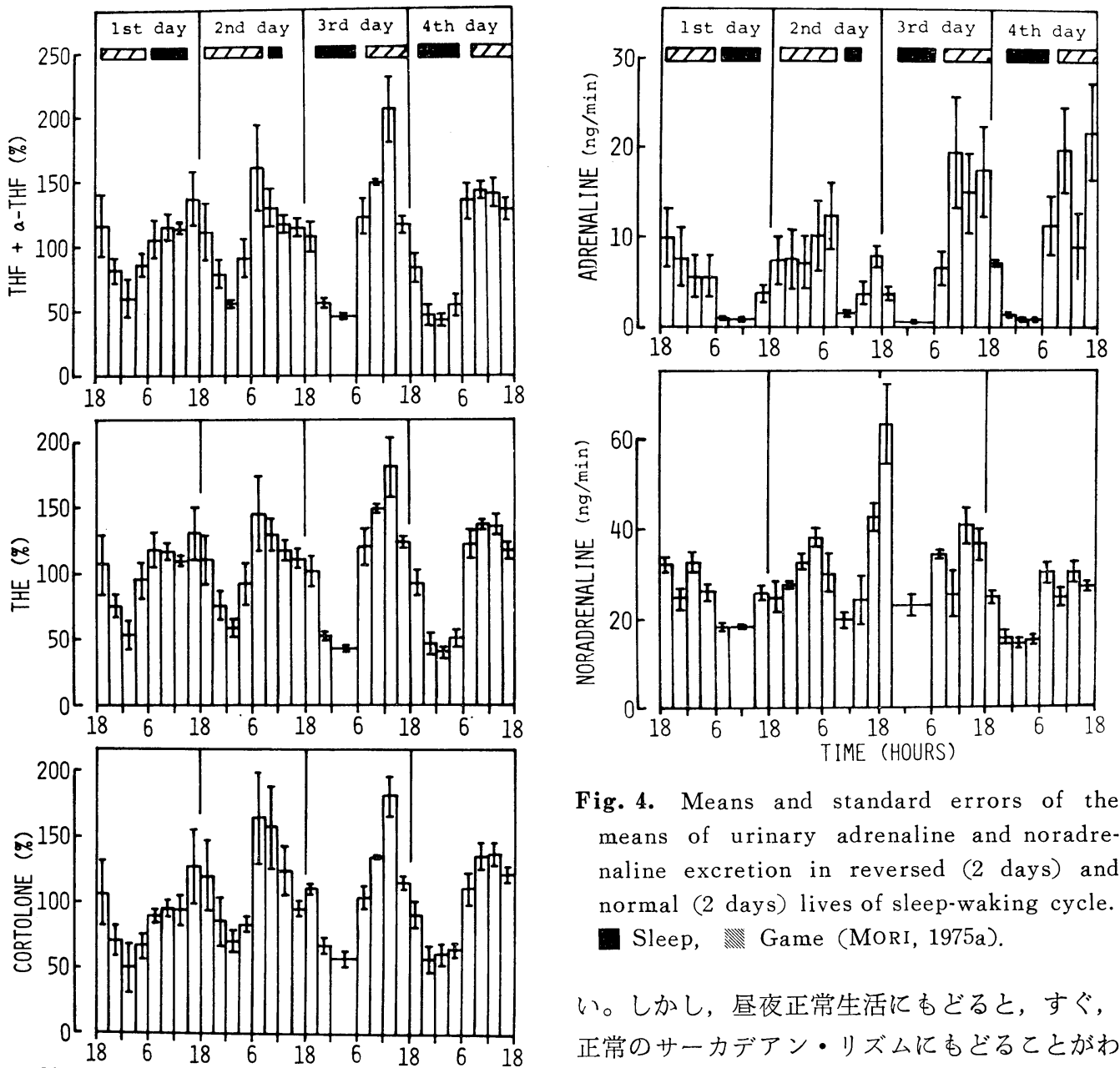

Fig. 4. Means and standard errors of the means of urinary adrenaline and noradrenaline excretion in reversed (2 days) and normal (2 days) lives of sleep-waking cycle.

Sleep, $\mathbb{N}$ Game (MORI, 1975a).

い。しかし，昼夜正常生活にあどると，すぐ， 正常のサーカデアン・リズムにもどることがわ かる。このととはすでに van Loon (1963) に よって指摘されている。

cortisol の代謝物, THF $+a$-THF, THE, cortolone, $\beta$-cortolone の変動は昼夜正常生活 にもどった 3 日目の振幅がとくに大きかった。 昼夜逆転生活時，いずれにすサーカデアン・リ ズムの逆転はみられなかった。昼間（9-15時） と夜間（0-6時）に分けて，4 日間を比較して みた（図 5 )。17-ヒドロオキシコルチコステロ イド (17-OHCS) は Porter-Silber 陽性物質 を比色定量したもので，THF， $a$-THF，THE はふくまれるが, cortolone 類, cortol 類はふ

くまれない。その変動は昼夜逆転生活をした最

Fig. 3. Means and standard errors of the means of urinary THF $+a-\mathrm{THF}, \mathrm{THE}$, cortolone, and -cortolone excretion (as percentage of 4 days mean value) in reversed ( 2 days) and normal (2 days) lives of sleep-waking cycle. Sleep, Game (Mori, 1975a). 

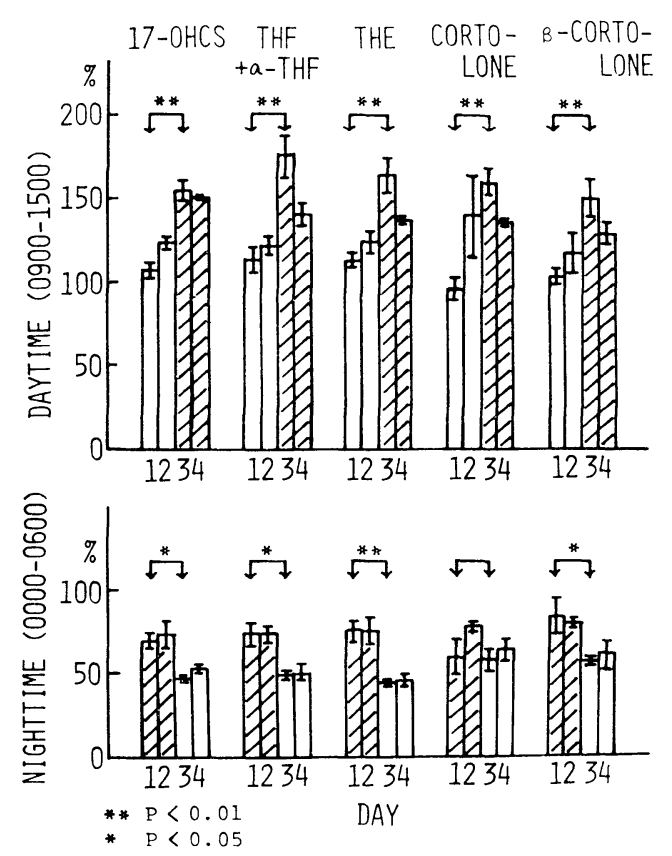

Fig. 5. Means and standard errors of the means of urinary cortisol metaborates excretion in daytime and in nighttime during game (column. with oblique lines) and sleep (open column) (MORI, 1975a).

初の 2 日間は振幅が小さく, 昼夜正常生活にも ぞった 2 日間では振幅が大きくなった。両生活 の各 2 日間については大きな差はなかった (守, 1974a)。図5 の代表的な指標 THE につ いてみると, サーカデアン・リズムの逆転は起 っていないので，昼間と夜間の差ははっきりし ている $(\mathrm{P}<0.01)$ 。ゲーム中と睡眠中の差は 夜間でははっきりしている $(\mathrm{P}<0.01) 。$ 㡺間で は2 日目の值が睡眠時間（9時30分〜13時）が 短いためか, やや1 日目より高い。また，4日 目が 3 日目にくらべて有意に低い $(\mathrm{P}<0.05)$ 。 そこで 2 日目と 4 日目の間には有意差はなかっ たが，他はゲーム中は睡眠中より有意に高かっ た。なお，3日目の12～15時の值がとくに高か った理由ははっきりしない。夜間のゲーム中で は $3 \sim 6$ 時の立上がりが大である。他の指標に ついては，17-OHCS では尽間の $3 ， 4$ 日目に
差がなく， cortolone では夜間 4 日間差がなか った。その他は THEとほぼ同じ関係が成立 した。つまり， cortisol 代謝物の尿中排泄のサ 一カデアン・リズムは 2 日間の尽夜逆転生活で は逆転は起乙らないが, 振幅が減少した。㡺夜 正常生活にもどった第 1 日目の12１5時の值は 少し高過ぎるようにも思われるが, 正常生活時 の振幅にもどるのは早いと考えられる。昼夜逆 転生活時, 舌下温のリズムのみだれの方が, cortisol 代謝物の尿中排泄のリズムのみだれよ り大きいようである。先に述べたように，視床 下部一脳下垂体一副腎系のサーカデアン・リズ ムは睡眠一覚醒のパターンの変化に同調しにく いことがわかる。

カテコールアミンはインドールアミンとなら ぶ生体アミンの一群で, adrenaline (ADR), noradrenaline (NOR), dopamine (DA) が これに属する。ADR と NOR は副腎髄質ホ ルモンとも呼ばれ，副腎䯣質に多く存在する。 脳内アミンとしては NOR と DA が主であ り, NOR は交感神経の終末端からも分泌され る。㽷中遊離型 NOR と ADR は血中濃度を 反映するといわれているので, てれらの尿中排 泄の変動を調べた。NOR, ADR ともゲーム 中高值, 睡眠中低值を示し, 尽夜逆転生活時に はサーカデアン・リズムは逆転し, 尽夜正常生 活にあどるとサーカデアン・リズムはすぐ正常 にあどった。2 日目と 3 日目の間の18～24時の NOR は異常に高い。その前が自由時間で, 入 浴したり，外出したりしているので原因ははっ きりしない。㡺間と夜間，ゲーム中と睡眠中に わけて図 6 に示した。NOR はゲーム中と睡眠 中の差ははっきりしているが，昼夜の差はな い。つまり完全なサーカデアン・リズムの逆転 がみられる。ADR の睡眠中の值は極端に低 く, サーカデアン・リズムの逆転はみられる が，ゲーム中の夜間の 1 日目之昼間の $3 ， 4$ 日 目の間には有意差 $(\mathrm{P}<0.01)$ があり, 固有の サーカデアン・リズムが逆転時にあ残っている 


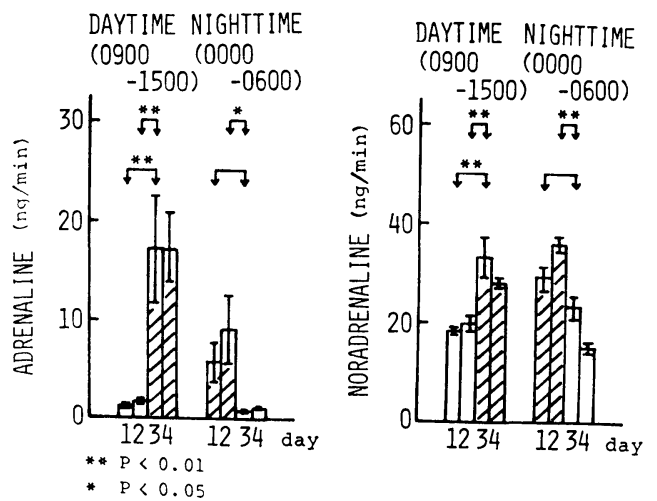

Fig. 6. Means and standard errors of the means of urinary adrenaline and noradrenaline excretion in daytime and in nighttime during game (column with oblique lines) and sleep (open column) (MORI, 1975a).

あのと思われる。断眠時に NOR のサーカデ アン・リズムは消失するが，ADR のサーカデ アン・リズムは存在するという報告とあ一致す る (FRÖBERG et al., 1972a)

3）不規則生活時におけるサーカデアン・リ ズム

前にあげた, cortisol 代謝物, NOR, ADR の尿中排泄量は睡眠一覚醒のサイクルを変えた 時, 三様にサーカデアン・リズムを変えて行っ た。PATKAI（1971）によれば，ゲームは快適 な負荷に属し，ADR の排泄を増加させたとい う。この実験はこのような負荷を連日かけて， 実験室的に生活パターンを作ったものである が，実生活においては負荷の強弱の組合せはむ っと複雑である。そてで, 負荷の強弱がサーカ デアン・リズムにいかに影響するかをみるため に，この実験に参加した検者の各指標の変動を 被験者の変動と比較した（守, 1975b)。舌下温 は両群とも昼夜逆転生活時にみだれ，昼夜正常 生活にもどると正常パターンを示した。逆転生 活時のパターンも両群で類似していた。17OHCS は検者群では 4 日間ともサーカデアン ・リズムに差はみられなかった。ADR は被験
者群では個人差ああったが一つの傾向を示して いた。活動のまちまちな検者群では，各個人が かなり異なる排泄パターンを示した。全体的に みて，睡眠時は低く，活動時は高かった。17OHCS ではサーカデアン・リズムは変わりに くく, ADR では活動水準による影響が大き く, 舌下温ではその間の変動を示したととにな る。
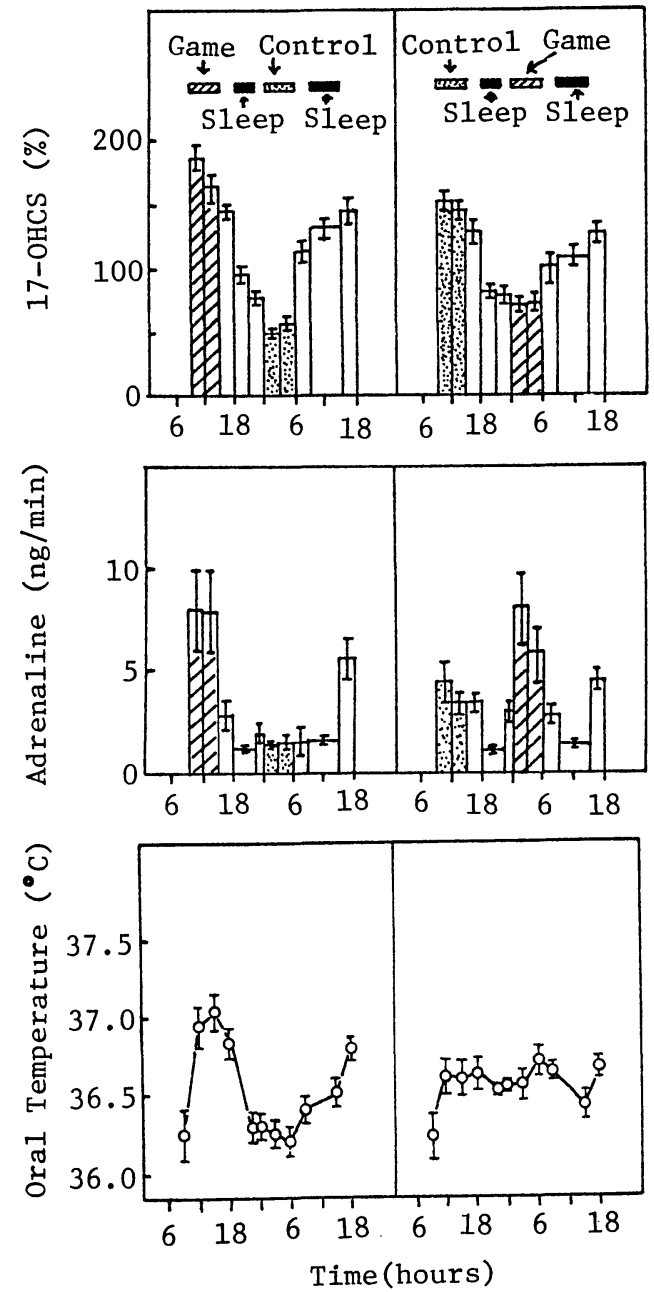

Fig. 7. Means and standard errors of the means of urinary $17-\mathrm{OHCS}$ and adrenaline excretion, and oral temperature in game session and in control session. W/l Game, $\because \because$ Control, DSleep (MORI, 1974b). 
4）昼夜における強弱の負荷に対する応答 被験者による強弱負荷実験を行なった（守， 1974b; 守, 1974c)。被験者は男子学生 8 名で昼, 間（9-15時）之夜間（0-6時）に麻雀ゲーム を負荷した実験と，特に負荷をかけない実験

（対照）を行ない, 約 3 時間毎に採尿し, 舌下 温, 脈拍数, 血圧, フリッカー值, 単純反応時 間を測定し，自覚症状しらべなどを行なった。 17-OHCS および ADR の尿中排泄と舌下温 の変動を図 7 に示した。負荷の強弱により, 17-OHCS は 9-12時と 0-3 時に有意差があ った $(\mathrm{P}<0.05)$ 。ADR は12-15時, 0 -3時, 3 - 6時に有意差があった（ $\mathrm{P}<0.05, \mathrm{P}<0.01$ ， $\mathrm{P}<0.01$ )。舌下温は12時, 15 時, 3 時, 6 時の

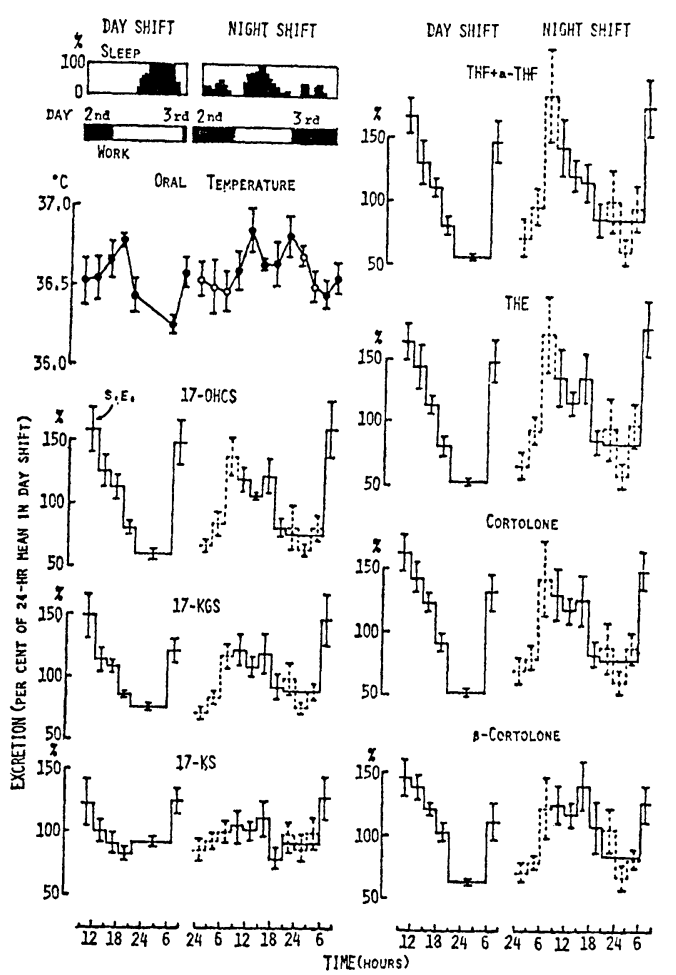

Fig. 8. Sleep pattern, and means and standard errors of the means of oral temperature and urinary corticoids excretion (as percentage of 24-hour mean value in day shift) in day and night shifts (MORI, 1973b).
すべてに有意差があった $(\mathrm{P}<0.01)$ 。昼間で あ夜間でも負荷をかけると，17-OHCS，ADR の尿中排泄量, 舌下温は負荷をとくにかけない 時より, 多かれ少なかれ増加する。従って, 負 荷の強弱によってはサーカデアン・リズムを修 飾してしまう可能性があることがわかった。

5） 2 日または 3 日交代の三交代勤務者のサ 一カデアン・リズム

実際の三交代制の職場の作業員の場合はどう であろうか。4 組 3 交代制（111222333明休日） の作業員 7 名の尿中 cortisol 代謝物の 変動之 舌下温の変動を調べた（守, 1973b)。実験は一 直の 2 日目の 9 時から 24 時間, 三直の 2 日目の 勤務中の 0 時から32時間行なった。被験者はす べて交代制勤務10年以上の経験をむち，既婚者 であり，乙のような生活に慣れていると思われ る。舌下温（図 8 ）は一直時（三直明から 5 日 目) は朝 6 時が最低で, 午後最高となる典型的 昼夜正常生活者のパターンであった。三直時 (2〜3 日目) はリズムの中では朝 6 時の值が 最低ではあったが, 一直時にくらべると高い傾 向にあった。また, 三直勤務前の21時が, 一直 の夜眠前の21時より有意に高值を示した（P> 0.01）。昼眠中または昼眠から目覚めた時刻に 相当する15時, 18時の值は一直時より低い傾向 にあった。三直時のパターンは COLQUHOUN et al. (1969) の実験室で行なった昼夜逆転生 活 6 日目のパターンに近づいているように思わ れる。尿中 cortisol 代謝物の変動を図 8 亿示 した。一直時のパターンは日常生活時の結果之 ほとんど同じであった。すなわち, 交代制作業 員も, 三直明から少なくとあ 5 日目には昼勤者 と同じパターンを持つ。三直明では，21-6 時 の平均排泄量は一直時にくらべ高値を示した (THE, $\beta$-cortolone では $\mathrm{P}<0.05$ で有意, $\mathrm{THF}+a$-THF, cortolone では有意とはなら なかったが非常に近かった)。また，昼間（9〜 15時) では三直時の值は一直時にくらべ低い傾 向にあった。一方, この職場における昼夜の仕 
事量は大差ないといわれている。しかし，作業 員のパーフォマンスは必ずしあ同じとはいえな いであろうし，負荷に対する感受性も昼夜で同 じであるかどうかわからない。結果としては実 験室で行なった前記の結果と大差はなかった。

5 組 3 交代制（112233明休日日）の作業員 9 名の睡眠時間の分布と尿中遊離型カテコールア ミンの変動について調べた(守ら,1973)。図9に 一直の作業開始時の 8 時から翌日の 8 時までの

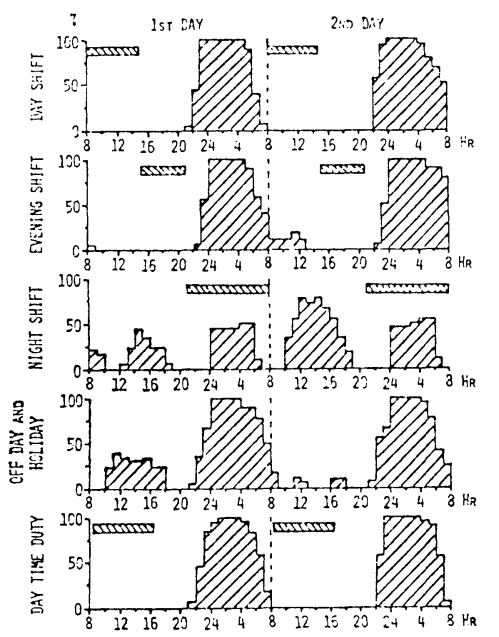

Fig. 9. Rate of sleeping in each one-hour period during consecutive 10 days of one cycle in a 5 team-3 shift system.

y) Sleep, Work (including $3-\mathrm{hr}$ nap in night shift and $1-\mathrm{hr}$ recess in day time duty) (MORI et al., 1973).

24時間を 1 日として 1 サイクル10日間の勤務時 間と睡眠時間の分布を示した。一直にくらべ二 直勤務前は起床が約 1 時間遅く, 二直勤務後の 就寝が約 1 時間遅くなる。三直第 1 日勤務前は 起床がさらに遅くなるが, 昼眠は短かい。三直 第 1 日目勤務後はかなり長く昼眠をとっている が, 三直第 2 日目の勤務後の三直明には昼眠は ほとんどとらず, 夕方早く寝て, 夜間の睡眠を 十分とっている。

採尿は一直 (1日目) の 8 時より 31 時間, 二 直（1日目）の15時より 24 時間, 三直（1日
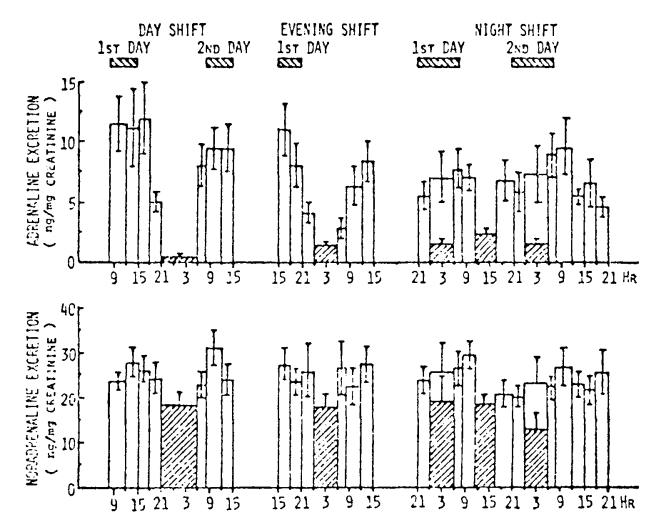

Fig. 10. Means and standard errors of the mean of urinary catecholamine excretion during consecutive two days of day, evening, and night shifts.

Whe Sleep, Work (including 3-hr nap in night shift and 1-hr recess in day time duty) (MORI et al., 1973).

目）の21時より48時間，図10に示すような間隔 で行なった。ADR は一直時と二直時と比較す ると朝6〜8時は一直時のほうがかなり多い。6 〜8時に寝ている作業員の割合は一直時約25\%, 二直時約 $50 \%$ 一直時の約 2 倍である。ADR の排泄量が睡眠によって影響されるととがわか る。また，18～21時の尿中排泄は勤務中の二直 時は就寝前の一直時にくらべ多い。乙れはいず れも覚醒中ではあるが，活動の差によるものと 思われる。夜間の睡眠中は一直時む二直時もか なり低值を示す。二直時の ADR の尿中排泄は 睡眠時間と勤務時間のずれに従って一直時より は位相がずれてはいるが，サーカデアン・リズ ムの振幅はほとんど同じである。また，乙のよ うな生活パターンによるずれは第 1 日目から成 立している。三直時の ADR 排泄を覚醒中に注 目してみると, 三直の朝 6 時までの勤務中は一 直, 二直時の勤務中の值よりやや低値を示す。 $6 \sim 8$ 時はやや上昇の傾向にある。三直第 1 日 目明の昼間は大部分が睡眠中なので覚醒時の值 ははっきりしないが，三直第 2 日目明は約 $30 \%$ 睡眠をとっているととを考慮にいれると一直, 
二直時の昼間の值にかなり近い。つまり振幅は 小さいが, $\mathrm{ADR}$ のサーカデアン・リズムは覚 醒中にも保たれているようである。三直睡眠中 の尿中 ADR の排泄量をみると, 夜間の仮眠中 の值は二直の夜眠中の值とほぼ同じである。三 直第 1 日目明の昼眠中の值は心持ち高值を示し ているが，昼眠にはいろいろの因子が入って来 るので，乙れだけでは本質的に昼眠と夜眠が異 なるかどうかはわからない。脳波の研究からは 昼眠と夜眠には差が観察されている（RUTENFRAZ et al., 1972)。 4 組 3 交代制の作業員10 名についての尿中遊離型カテコールアミンの変 動も上記 5 組 3 交代制の場合の結果とほとんど 同じであった（守ら，1974）。

6）正常生活時と断眠時のサ一カデアン・リ ズム

スウェーデンの Laboratory for Clinical Stress Reseach の Levi 一門も交代制勤務時 のサーカデアン・リズムに関連して, 尿中遊離 型カテコールアミン排泄量と自己評定注意集中 度 (self-ratings of alertness) の関係につい て広範囲な研究をしている (FRÖBERG et al., 1972a; FRÖBERG et al., 1972b; АNeRSTEDT et al., 1975)。乙れは四つの研究からなる，す なわち，1）正常生活時，2）断眠実験，3） 夜勤未経験者の 3 週間連続夜勤，4）三交代勤 務。

正常生活においては，ADR, NOR の排泄パ ターンも selfrated alertness あ昼間高く, 夜 間低い，ふつうのサーカデアン・リズムを示 す。

75時間の断眠実験では, 完全に外界と遮断し た部屋で， 3 時間毎に採尿し， $300 \mathrm{ml}$ の水々 2 枚のサンドイッチを与え，食事の間に質問表 に答を書かせた。残りの 2 時間45分には射撃を 負荷した。図11に結果を示した。ADR の尿中 排泄之自己評定疲労度之は逆相関の関係にあ り，断眠により24時間覚醒状態にあるにあかか わらずサーカデアン・リズムは保たれていた。

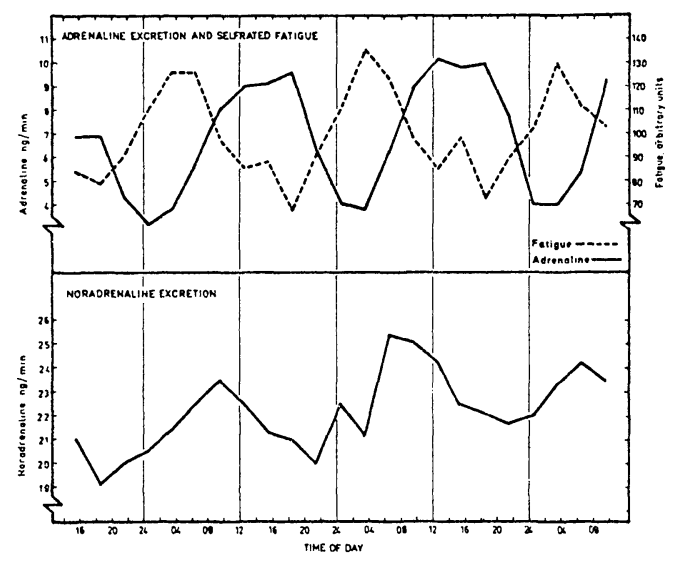

Fig. 11. Means of urinary excretion of adrenaline and noradrenaline, and self-ratings of fatigue, over 72 hours of continuous work. $\mathrm{N}=29$ (Increasing trend in fatigue curve removed) (ÅKERSTEDT et al., 1975).

NOR のサーカデアン・リズムはかなりみだれ ていた。

7）長期夜勤時のサーカデアン・リズム 夜勤未経験者としては昼勤者を選び，夜勤を 3 週間連続で行なわせたが, 土, 日曜日は休日 とした。夜勤に入る前の週の昼勤時に 1 回, 夜 勤 1 週目に 1 回, 3 週目に 1 回, 夜勤後の昼勤 の 1 週目に 1 回, 24 時間にわたり $7-8$ 回採尿 し, selfrated alertness を記入させた。ADR の排泄は夜勤前後の尽勤時はともに非常によく 似たパターンを示した。夜勤時のパターンはい くらか複雑になる。第 1 週目には昼夜正常生活 時のサーカデアン・リズムが根強く残ってい る。昼眠前後の排泄量が昼勤時よりかなり高い ので, 尽眠時值は低くなっても, 夜眠時の 3 倍 以上となり, 昼勤時の同じ時間帯の值とあまり 違わなかった。第 3 週目には昼夜逆転生活への 適応がみられたが, 振幅は小さかった。昼夜正 常生活にあどると前に記したように，すぐ正常 パターンにあどった（図12）。昼勤時の selfrated alertness は前後の昼勤時はと屯に昼間高 く, 夜低い典型的サーカデアン・リズムを示し 


\section{ADRENALINE EXCRETION}

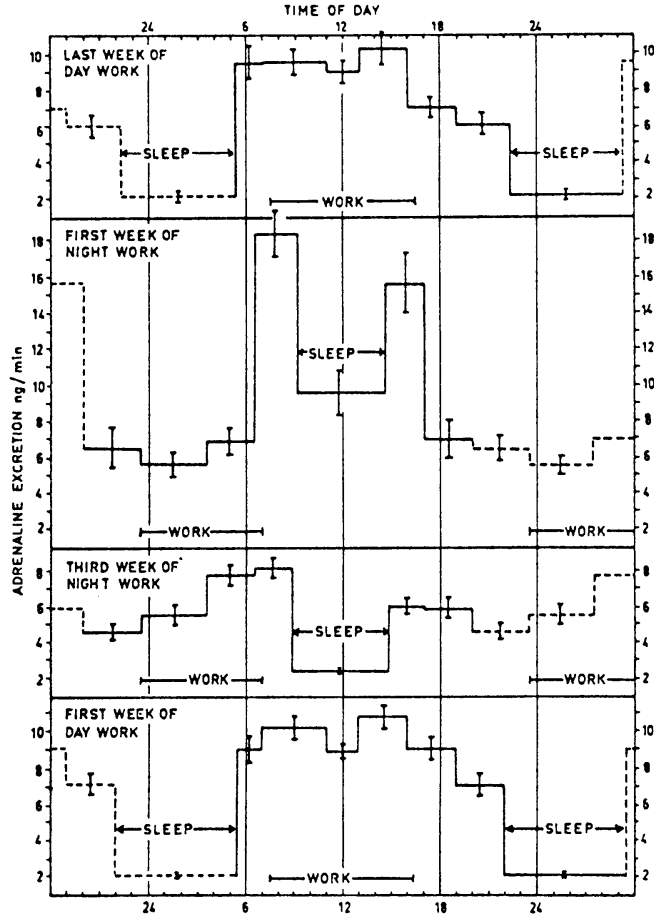

Fig. 12. Means and standard errors of urinary adrenaline excretion for 24 hours during : last week of day work, first week of night work, third week of night work, first week of day work. $N=15$. In order to stress the temporal factors the data have been repeated beyond the 24-hour points by a broken line

(ÅKERSTEDT et al., 1975).

たが，夜勤時は振幅が小さくなり，はっきりし たサーカデアン・リズムを示さなくなった。

NOR は夜勤の前後の昼勤時には立上がりの早 いサーカデアン・リズムを示し，夜勤に入ると $\mathrm{ADR}$ より早く適応を示す。㡺勤にもどるとそ のパターンも正常にすぐもどる。とのような変 化の心理生理学的意味についてははつきりしな いと著者らは述べている。2）尽夜逆転生活時 とその回復過程の項で述べたように守 (1975a) も NOR の尿中排泄が昼夜逆転生活時すぐに 睡眠一覚醒のサイクルに同期し，昼夜正常生活 にもどるとすぐもとのパターンにもどるという
結果を得ている。

8）約 1 週間交代の三交代制勤務者のサーカ デアン・リズム

三交代制勤務者については勤務中のみの測定 であった。勤務の形態は少し複雑で， 1 直 6 日，2直 7 日，休日 4 日，3直 7 日，休日 4 日 が一サイクルであった。各直の 2 日目または 3 日目と 5 日目または 6 日目に測定を行なった。 結果を図13に示した。 3 直の 6 日目の勤務中が

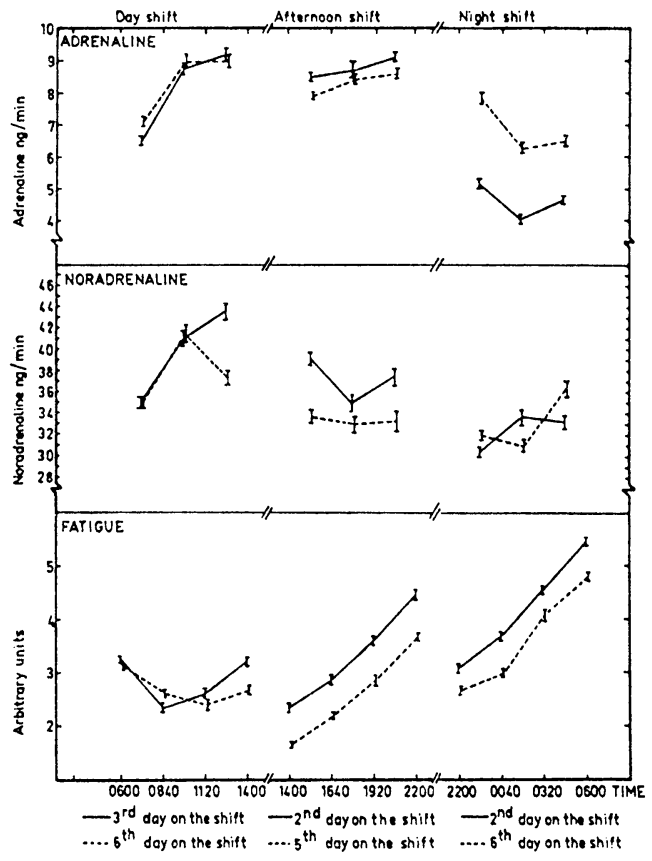

Fig. 13. Means and standard errors of urinary adrenaline, noradrenaline excretion, and selfrated fatigue for near the beginning and near the end of day, afternoon and night shift "weeks" respectively ( $\AA_{\mathrm{K} E \mathrm{RSTEDT}}$ et al., 1975).

2 日目より ADR の排泄量が多くなっているの が目立つ。これは適応によるのか。また, 疲労 度が, 2 直と 3 直では時間経過とともに上昇し， 5 日目または 6 日目の方が 2 日目より值は低 い。乙れも適応によるのか。

カテコールアミンであるアドレナリンもノル 
アドレナリンも，また，自己評定注意集中度も とあにサーカデアン・リズムを示すが，乙れ らは必ずしも活動のパターンに従ってはいな い。例えば， 3 日間断眠をさせて，負荷をかけ つづけても，アドレナリンや自己評定注意集中 度は昼高く夜低いリズムを維持しつづける。夜 勤を長期間続けると昼夜正常生活のパターンか ら位相はづれてくるが，完全には逆転しない。 それなのに，昼夜正常生活にもどるとすぐすと のリズムにもどってしまう。つまり，昼夜正常 生活時のパターンはかなり強固に残るととにな る。夜勤未経験者が夜勤をはじめた第 1 週目, 三交代制勤務者の夜勤の週のはじめにはっきり とこの事が観察された。従って, 夜勤の勤務 中, 交感神経系は比較的不活性な状態にあり, 睡眠をとらうとする昼間に逆に交感神経系が活 性となるという結果を生んでしまう。てれは RUTENFRANZ ら（1972）の昼眠は夜眠とは定 性的にも定量的にも異なるという見解とも符号 すると ÅKERSTEDT ら (1975) は結論してい る。

3.コサイナー法

サーカデアン・リズムのずれを調べる解析法 の一つに HALBERG et al. (1967) の開発した コサイナー（cosinor） 法がある。これは, デ ータに最も近似するコサインカーブを最小自乗 法で求め, 得られたデータを座標変換して極座 標の上に示し, リズムの頂点位相, 振幅, 環境 サイクルなどが一見してわかるように描いたも のである。彼等はこの方法を用いて多くの知見 を見いだしているが，コサイナー法では原波形 のニュアンスを見ず，強引にコサインカーブに のせてしまうという点で問題であるとする研究 者むいる。

$$
\text { おわりに }
$$

Levi 一門の結果とわれわれの結果之はアプ ローチの仕方に若干の違いはあるが, 非常に類 似した結果である。ここで述べたように，夜勤 の研究では一般に完全な適応は難かしい。しか
し, 東西方向へのジェット機での旅行はてれに 比較して適応しやすい (LAFONTAINE et al., 1967 ; HALBERG, 1969)。時差のある場所への 移動は, 明暗屯周囲の環境屯完全にその場所の あのに変化してしまう。ところが, 夜勤では, 外部の太陽はやはり尽輝き, 家庭をふくめた一 般社会は昼夜正常の生活をしている, また, 夜 勤者は夜中の12時を正午とは考えないであろ う。また，休日は昼夜正常またはそれに近い生 活をするであろう。あともとリズムは逆転しに くい上に，休日にはもとにあどり易い。乙んな 状態なので, 夜勤への完全な適応というのは起 こらないと現在では考えられている。

多くのホルモンのサーカデアン・リズムの研 究はその微量測定法の進歩とあいまって, その 発現機構にせまる基礎的な研究分野に，また疾 患之関連して医学の領域に拡がっている。東西 旅行とか交代勤務のような実生活に結びつく応 用的研究分野での種々のホルモンの動態の解明 される日も近いことを期待して稿を終る。

\section{文献}

ÅkERSTEDt, T. and J. E. FröberG, 1975: Work hours and $24 \mathrm{~h}$ temporal patterns in sympathetic-adrenal medullary activity and self-rated activation. Colquhoun, P., S. FOLKARD, P. KNAUth and J. RUTENFRANZ (ed.) "Experimental studies of shiftwork", Forschungberichte des Landes NordrheinWestfalen, Nr.2513, Westdeutscher Verlag, Opladen, p. 78-93.

Aschoff, J., 1967: Human circadian rhythms in activity, body temperature and other functions. Life Sciences and Space Research, North-Holland Publishing Co., Amsterdam, p. 159-173.

Colquhoun, W.P., M.J.F. Blake and R.S. EDWARDS, 1969: Experimental studies of shift-work III: Stabilized 12-hour shift systems. Ergonomics, 12: 865-882.

出口武夫, 1975: 生物時計の個体発生之周期 性. 科 学, 45: 522-529.

FröberG, J., C,-G. KarLsSON, L. LeVi and L. 
LIDBERG, 1972a: Circadian variations in performance, psychological ratings, catecholamine excretion, and diuresis during prolonged sleep deprivation. Int. J. Psychobiol. 2: 23-36.

FröBERG, J., C.-G. KARLSSON and L. LEVI, 1972b: Shift work: A study of catecholamine excretion, self-ratings and attitudes. SwENSson, A. (ed.) "Night and shift work", Studia Laboris et Saluties, 11: 10-20.

Gallagher, T.F., K. Yoshida, H. D. RoFFWARG, D. K. Fukushima, E. D. Weitzman and L. HELlmAN, 1973: ACTH and cortisol secretory patterns in man. J. Clin. Endcrinol. Metab., 36: 1058-1068.

Halberg, F., 1959: Physiologic 24-hour periodicity; general and procedural cosiderations with reference to the adrenal cycle. Z. Vitamin-Hormon- und Fermentforsch, 10: 225296.

HalberG, F., 1969: Chronobiology. Ann. Rev. Physiol., 31 : 672-725.

HAlberG, F., Y.L. TONG and E. A. Johnson, 1967: Circadian system phase-An aspect of temporal morphology; procedures and illustrative examples. H.v. MAYERSBACH(ed.) "The cellular aspects of biorhythms", Springer, Berlin, p. 20-48.

Hellman, L., F. Nakada, J. Curti, E. D. Weitzman, J. Kream, H. ROFFWARG, S. Ellman, D. K. Fukushima and T.F. GALLAGHER, 1970: Cortisol is secreted episodically by normal man. J. Clin. Endocrinol. Metab., 30: 411-422.

広重力, 1972: ACTH 放出因子活性の日内リズム. ホルモンと臨床, 20:169-176.

Hiroshige, T., M. SAKAKUra and S. Itoh, 1969: Diurnal variation of corticotropinreleasing activity in the rat hypothalamus. Endocrinol. Jap., 16: 465-469.

井村裕夫, 1976：睡眠と下垂体ホルモン分泌. 非村裕 夫, 宮井潔編 “脳とホルモン”, 医霜薬出版, 東京, p. 125-152.

LaFontaine, E., J. Lavernhe, J. Courillon, M. MedvedefF and J. GHATA, 1967: Influence of air travel east-west and vice-versa on circadian rhythms of urinary elimination of potassium and 17-hydroxycorticosteroids. Aerospace Med., 38: 944-947.

van Loon, L. H., 1963: Diurnal body temperature curves in shift workers. Ergonomics, 6: 267-273.

守和子, . 1973a：OV-210カラムを使用したガスクロ マトグラフィーによる人尿ステロイドの日内変動の 検討. 産菜医学, 15：176-177.

守和子，1973b：三交替制作業員の 尿中コルチコイド の日内変動. 産業医学, 15：440-441

守和子, $1974 \mathrm{a}$ ：夜勤中と夜勤後のコルチコイドとカ テコールアミン排泄の日内変動 (第 1 報). 産業医 学, $16: 566-567$.

守和子, 1974b : ストレッサー暴露時の日内変動（第 2 報)、第47回日本産業医学会, 第16回産業医協議 会講演集，402-403.

守和子, 1974c: コルチコイドとカテコールアミンの 尿中排泄におよぼす日内リズムとストレッサーの影 響. 日内分泌誌, 50:336.

守和子, $1975 \mathrm{a}$ : 夜勤中と夜勤後のコルチコイドとカ テコールアミン排泄の日内変動 (第 2 報). 産業医 学, $17: 36-37$.

守和子, 1975b : 交替勤務と 不規則勤務時のコルチコ イドとカテコールアミンの日内リズム．第48回日本 産業衛生学会, 第18可日本産業医協議会講 演集, 243-235.

守和子, 阿部完司, 1971：日常生活時における尿中中 性ステロイド，4-ヒドロキシー3-メトキシマンデル 酸および電解質の日内変動. 産業医学, 13:552553.

守和子, 加藤寿一, 須藤綾子, 1974 ：某装置店業に従 事する 3 交替制作業員についての生理学的調查（第 3 報). 産業医学, 16:492-493.

守和子, 須藤綾子, 柿崎敏雄, 加藤寿一, 1973：某装 置虐業に従事する三交替制作業員についての生理学 的調査（第 2 報）カテコールアミンと踖眠. 産業医 学, 15: 442-443.

Ney, R. C., N. Shimizu, W. E. Nicholson, D. P. IsLAND and G. W. LIDDLE, 1963: Correlation of plasma ACTH concentration with adrenocortical response in normal human subjects, surgical patients, and patients with Cushing's disease. J.Clin. Invest., 42: 16691677.

PAtKAI, P., 1971: Catecholamine excretion in pleasant and unpleasant situations. Acta 
Psychologica, 35: 353-363.

Pincus, G., 1943: A diurnal rhythm in the excretion of urinary ketosteroids by young men. J. Clin. Endcrinol. Metab., 3: 195-199.

RutenfRANZ, J. and P. KNAUTH, 1972: Investigation of the problems concerning influences upon the sleep of shift workers. Swensson, A. (ed.) "Night and shift work", Studia Laboris et Saluties, 11: 58-65.

吉田尚, 1972：水代謝. ホルモンと臨床，20：193197.

（1977年 1 月26日受付）

\title{
Hormones and Circadian Rhythm
}

\author{
Kazuko MORI \\ Department of Industrial Physiology \\ National Institute of Industrial Health
}

In the former part of this paper are given the general remarks over the studies on the circadian rhythms in hormones.

Described in our papers were the circadian rhythms of oral temperature, the pituitary-adrenal cortical and the sympathetic-adrenal medullary systems, and their responses to the phase shift of waking and sleeping times. The papers included five subjects-patterns of excretion for normal day work, patterns during and after experimental night shift, patterns during experimental irregular shift work, responses to different work loads in daytime and at night, and patterns of three-shift workers.

Reported from Levi's laboratory in Sweden were the circadian properties of the sympatheticadrenal medullary system and its responses to changes of activity phase.

The paper is divided into four parts-patterns of excretion for normal day work, patterns during continuous 24 hour activity, reactions in normal day workers suddenly exposed to a $180^{\circ}$ work phase shift, and finally patterns of experienced three-shift workers. The desynchronization of different variables were recognized with the synchronization among some variables after the phase shift.

A complete re-entrainement of circadian rhythms were not obserbed during the night shift. After the change back to day work re-entrainement seems to have occurred relatively quickly. 